\title{
ガラス面培養細胞の 電子顕微鏡的観察法
}

渡辺 強三, 新島 迪夫 東京医科歯科大学医学部解剖学教室

\section{1. まえがき}

培養細胞を電顕で観察するには 2 つの方法がある. 1 つは，培養細胞が一般の組織の場合とらがって，うすく ひろがっていることを利用して、これを薄切すること なく、そのまょッシュにのせて観察するやり方であ る21 26)，この方法では，標本が厚いために，こまかい 観察が困難である.

第2は，普通の標本の場合の上らに，薄切して観察す る方法である。このためには, 培養細胞を一般組織の場 合と同様に樹脂に包理する心要がある.ガラス面に培養 した細胞を包理する際に，樹脂がカプセルと細胞の付着 しているカバーグラスとの吵間から流出することや，包 埋剂として methacrylate 樹脂でなく, epoxy 樹脂を 用いると，この樹脂が重合後にカバーグラスからはがし にくいことなどの支障があるので，これらについて，従 来種々の工夫が試みられてきた。

また，生きた状態で位相差鏡検をした特定の細胞を電 顕で観察したいことがある.この場 合，薄切のとき目ざす細胞を捕捉す ることについては, これまで充分満 足すべき結果が得られていなかった.

ガラス面に培養した細胞の固定や 脱水法などについては，その特殊性 のために，一般の組織細胞のそれと はかなりちがった技術が必要である が，ここでは誌面の都合上割愛し， 私どもの教室で用いている包埋装置 と, 1 個の目的細胞の薄切法を中心 として述べることにする。

\section{2. 包埋剤と剥離 のための前処理} 包埋斉は, 以前は methacrylate

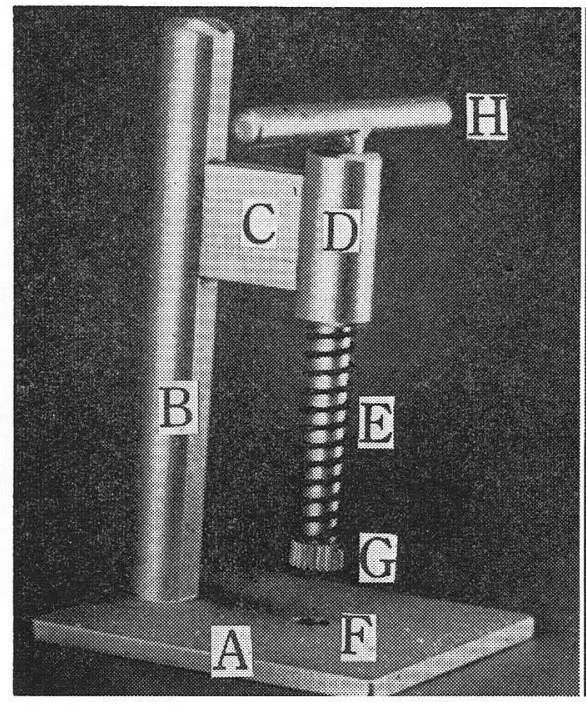

図1包埋装置

樹脂が多く用いられていたのであるが，今ではふつう， epoxy 樹脂が用いられている. methacrylate 樹脂を用い た場合には，重合後ブロックをドライアイスの上にの也 て冷却するだけで，培養に用いたカバーグラスを細胞を 包埋した樹脂からはがすことが容易である12 16,18,27,37).

しかし，epoxy 樹脂の場合にはこれが困難であり，これ に対しても多くの工夫がなされてきた.すなわち，カバ

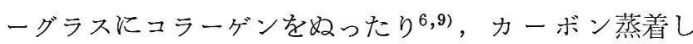
たり ${ }^{3,7,29 \sim 31,35)}$ ，シリコン SC-77 (General Electric Corp., Waterford, N. Y.) を如たり ${ }^{32)}$, 染色体の研 究においてシリ コン(G.E. Dri-film) ${ }^{9)}$ や Siliclad (GlayAdams Inc., N.Y.) ${ }^{15,34)}$ も用いられている.

私どもの教室では,もっぱらンリコン KC 88 (信越化 学)を用いて目的を果たしている ${ }^{36)}$ 、すなわち, カバー グラスを充分清浄にし，シリコンの 1 滴をこの上に落と し，ひろげてうすい膜とする.この際，カバーグラスの 裏側にまでシリコンがつくと，次の隇菌のときにその容 器（ガラスシャーレ）の底にねばりついて，はなれにく くなるから, 注意を要する。

次に $180^{\circ} \mathrm{C}, 30$ 分間乾熱滅菌し，これにプラズマク ロット培養を行なう，蒸着装置があれば, シリコンの代 わりとカーボンを用いても差しつかえない。

\section{3. 樹脂の流出の防止法}

ふたを除き，樹脂をあらかじめ入れておいたカプセル の縁を下向きにして，すでに固定，脱水を行なった培垗 細胞の付いているカバーグラスの標本の上に, 倒立被覆

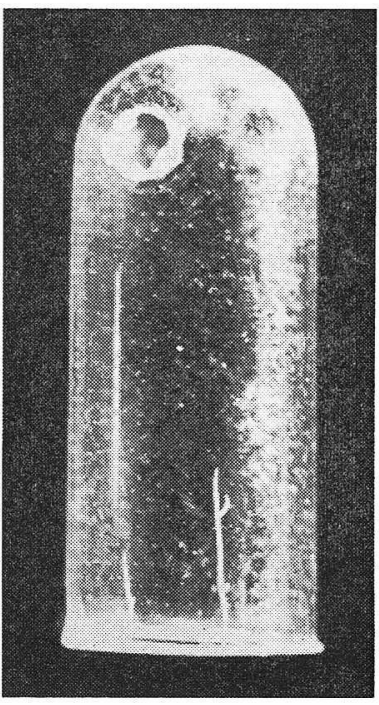

図 2 カプセル

Vol. 6, No. 7 
して包埋したり，あるいは倒立した空のカプセルの底か ら孔を通じて樹脂を流しこむ方法が従来行なわれてい $た^{1 \sim 4,9,10,12,13,15,19,27 \sim 31,34,37)}$. この場合, カバーグラス と倒立したカプセルとの吵閒から包埋用の樹脂が流出し やすいことは, methacrylate 樹脂ほどではないが, 樹 脂がガラスからはがれにくいこととともに，培羕細胞の 電顕観察上の障碍になっていた。これを防ぐために，い ろいろの工夫がされてきた。これには，包埋装置の考 案 $3,6,15,19,28,33,34)$ と, 樹脂の粘稠度の工夫がある $1,8,11$, $12,14,15,28,29,31,34,36)$.

私どもは次のような取扱いの便利な装置を考案し(36), さらにカプセルに操作を加光，今まで一部に行なわれて いた半重合をしないでも，流出することのない方法を用 いている.

i ) 包埋装置（図 1)：中央に径 $5 \mathrm{~mm}$ の孔(F)を 有する方形の金属板台 $(\mathrm{A})$ とその一隅值立する支柱 (B)，祘よび支柱から板台の中央へ向かって水平汇出る 腕（C）と，その先端のピストンガイド (D) を通じて 重直に下方へ向からバネを有する押壳ピストン（E）と から成る. 板台の上以固定, 脱水して培着細胞の付着し たカバーグラスを怙き，目的とする細胞の所在が孔（F） の中央にくる上らに位置させ，後述のように処理したカ プセルをこの上に倒立させ，ピストンを降ろして，接触 端 $(\mathrm{G})$ をカプセル底にあてがい，バネで押劣る・ピス トンには水平の柄 $(\mathrm{H})$ があり，その一端を支柱 $(\mathrm{B})$ の頂上にの世ることができるように，そこに溝をつくっ てあるから，カプセルの倒立被覆の操作中ピストンを上 方に止めて吩くことができる。もちろん，この装置は金 属板台をさらに大きくして, 数個, 取り付けることがで きる.

ii) カプセルの処理（図 2): Lilly, No.0 のカプ セルを使用している. カプセルの口縁は平担でないこと がしばしばあるので，あらかじめ少し熱した載せガラス にカプセルの口縁をやや圧し気味に垂直にあてると，縁 织厚く, 平らになる. 次に, カプセルの底の近くに樹脂 注入用の 2 つの孔をあける。

\section{4. 重 合と剝離}

包理装置にとりつけた倒立カプセルに底の孔から樹脂 を注入し， $60^{\circ} \mathrm{C} て ゙ 12 \sim 20$ 時間重合させる。次に，これ をガラスから豩離するには，ドライアイスの上にブロッ クをのせて，冷却すれば， methacrylate の場合と同様 に，数分で容易にはがれる ${ }^{7,29,30,35,36)}$. 涷結切片用の凍
結装置があれば，その凍結板をドライアイスに代えるこ とができる19).

\section{5. 目的細胞の薄切}

位相差顕微鏡で観察し，または $16 \mathrm{~mm}$ 映面に記録し た特定の培養細胞を，電顕で観察しらるようにすること が，私ぞもの当面の目的である. 薄切すべき目的細胞の 捕捉法はこれまでもいくらか陚みられているが，複雑な あったり不確実であったりして，充分に满足できるるの はまだなかった、Nebel（'56）の方法では1個の細胞を では行かず, Howatson ら ('58), Latta ('59) はシャー レで培養, 固定, 脱水, 包埋 (methacrylate) を行ない, 薄い周辺部の樹脂中の細胞を顕微鏡下に選んでいる。 た Falcon dish に培養し，ここで固定，脱水，包埋重合 の後，目的とする細胞のところに印をつけておき，コル クへの穴あけ器でこの部分の薄い樹脂を抜き取り, 再包 埋して薄切する方法"5とっている，また Bloom ('65) は染色体の研究において, 先細りの透明な樹脂の棒の先 端に特殊な装置を使って，目的とする細胞を含む樹脂を つけ，あるいは電気クランク鋸を用いて樹脂を切り取り。 金属か木の台に取りつけたり イヤモンドナイフ，貴金属細工鋸などで印をつけたりし ている3,15,35)。また，組織を含むカプセルの端を鋸で 2 $\mathrm{mm}$ ぐらいの厚さに切って, 顕微鏡で目的域を選定し, これを再包埋して薄切する方法"9や，カバーグラスの代 わりに $1.5 \mathrm{~mm}$ の厚さの樹脂のスライドに培養し, 包 埋重合後にダイヤモンドナイフなどで目的の細胞の近く に印をつけてトリミングする8)など，いるいるな工夫が あるが，私どもは次のような簡単で確実な方法を用いて， 好結果を得ている.

すなわら，上述の万法で剥離した組織を含むカプセル

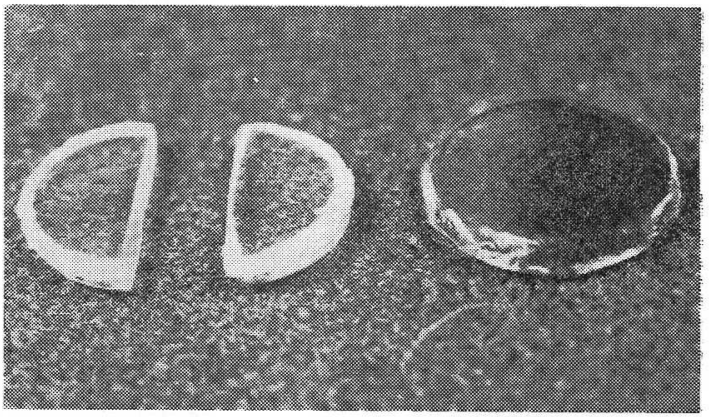

図 3

右 : 薄片にした図 4 の緗胞を含んた樹脂（厚さ約 $1 \mathrm{~mm}$ ) 左 : 同一培養細胞群から 2 個の細胞を薄切する場合 


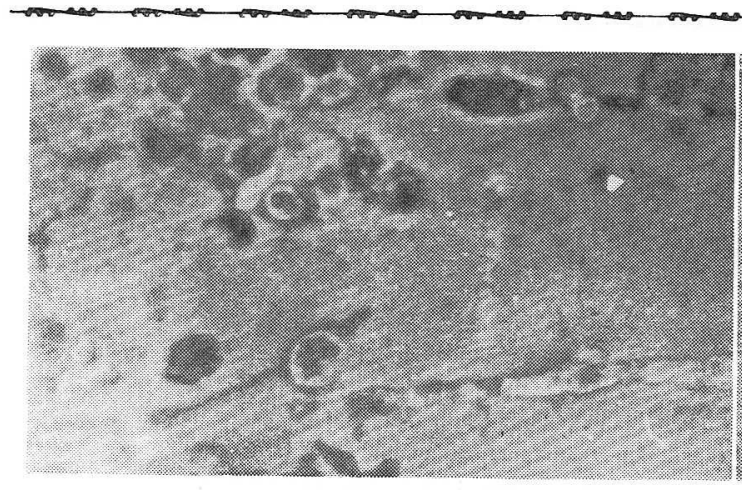

図 4 目的培養細胞の位相差顕微鏡像 $16 \mathrm{~mm}$ 咉画フィルムから扛人

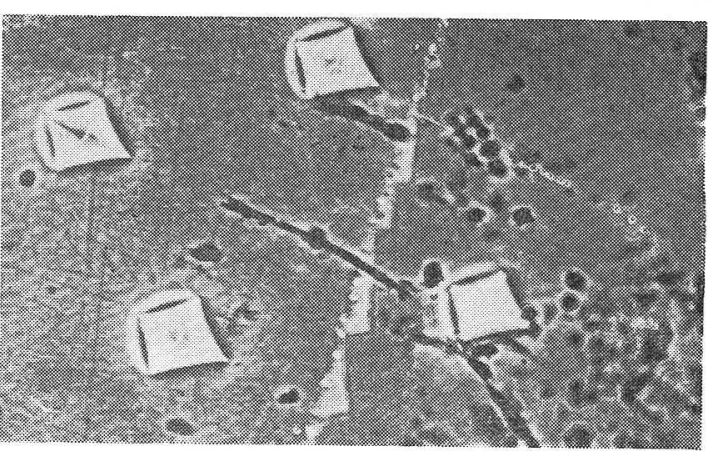

図 5 図 3 の右側の薄板内の組織の拡大図(位相差顕徽鏡) 4 㮯の印がつけられた真ん中に，目的の細佨（図4の細胞） が見える。

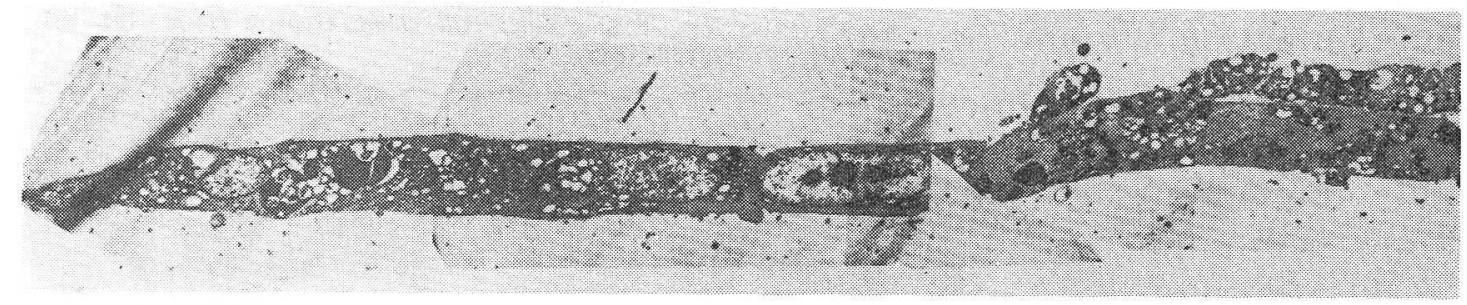

図 6 図 4,5 の目的細胞の電子顕微鏡像

の端を $3 \mathrm{~mm}$ ぐらいの厚さに切断する.この断面を 600 〜700, 800 メッシュのエミリーペーパー（研磿紙）で こすり, 最終の厚さが $1 〜 1.5 \mathrm{~mm}$ の小板とし, 最後に テルキジン（樹脂艶出し）でみがくと，樹脂は透明とな る (図 3).これを位相差鏡検すると, 包埋されている細 胞がよく見える.この像を固定直前の生時の位相差観察 の所見と照合すれば，目的の細胞を認識することができ る. $16 \mathrm{~mm}$ 顕微鏡映画を用いると, 生時の細胞の運動 状沉と電顕的構造とを対比することができる（図 4 ).

次に,この細胞に marking apparatus（顕微鏡の接 物鏡取付口にはめこんで，顕微鏡載物台上の標本に印を つける器具）学用いて印（図 5) をつける。同一標本の 中に， 2 個または 3 個の锥察したい細胞が離れて存在す る場合には，それぞれの細胞を含む樹脂の部分を小片に 分断（図 3 左）すれば，1個以上の目的細胞を別々に取 り扱らことができる.こうして，この樹脂薄板を細胞の ある面を表にして, 他のブロックに再包埋し, 双眼実体 顕岍鏡下に，上述の方法でつけた印を目あてにしてトリ ミングすする.

平たくのびた 1 個の細胞を切線方向に薄切するには, 細胞がブロックの表面近くに位置するのであるから，切 り始めの切片から, 観察可能の薄いものでなければなら ないので，薄切技術には熟練していることが必要である.
な寺，目的となる細胞がメッシュの陰にかからぬよう， 目のあらいものを使らほらがよい。

この方法によれば，生きているときに，位相差顕微鏡 で観察して目をつけて拐いた培湌細胞を，電顕で確実に 観察することが可能なので，この方面の斫究に役立つも のと思ら。また，この包埋法や，カバーグラスからの剥 離法は, 染色体, 原虫, 各種小生物などの包埋, 薄切に も応用できるであろう。

\section{文献}

1) E. Borysko:J.B.B.C., 2, Suppl., 215 (1956).

2) Idem:Ann. N.Y. Acad.Sci., 90, 353 (1960).

3) W. Bloom : J. B. B.C., 7, 191 (1960).

4) W. Bloom and R.J. Leider : J. Cell Biol., 13, 269 (1962).

5) B. R. Brinkley, Patricia Murphy and L. Carole Richardson: ibid., 35, 279 (1967).

6) R.P. Bunge, M.B. Bunge and E.R.Peterson: ibid., 24, 163 (1965).

7) R. Devis and D.W. James: J. Anat. Lond., 98, 63 (1964).

8) J.Egeberg : Stain Techn., 40, 343 (1965).

9) H. Gay : ibid., 30, 239 (1955).

10) S. Heyner : ibid., 38, 335 (1963).

11) S. Heyner and M.S. Israel : Exp. Cell Res., 30, 236 (1963).

12) A.F. Howatson and J.D.Almeida: J. B. B. C., 4, 115 (1958)

13) S.P. Jackson and R.H.Smith : ibid., 3, 897 (1957). 
14) H. Latta : ibid., 5, 405 (1959).

15) J. Micou, C. C. Collins and T. T. Crocker: J. Cell Biol., 12, 195 (1962).

16) B. R. Nebel and O.T.Minick: J. B. B. C., 2 (4), Suppl., 61 (1956).

17) M. Niizima : Proc. 2nd Ann. Gen. Meet. Jap. Histochem. Ass., 57 (1961).

18）新島迪夫, 中村逸雄, 渡辺強三, 平光属司 : 解剖学雑誌, 36, 356 (1961).

19) M. Nishiura and S. R. Rangan : J.B.B.C., 7, 411 (1960).

20）新島迪夫, 渡辺强三：日本組織培養学会, 第 24 回研究 会, 1967 .

21）小倉光夫：日本生理学雑誌，14，145 (1952).

22) G.E.Palade and K. R.Parter:J. Exp. Med., 100, 641 (1954).

23) K. R.Porter, A. Claude and E.F.Fullam : ibid., 81, 233 (1945).

24) K. R.Porter and H.P. Thompson: Cancer Res., 7, 431 (1947).
25) Idem:J. Exp. Med., 88, 15 (1948).

26) K. R.Porter, : ibid., 97, 727 (1953).

27) K.R.Porter and G.D.Pappas, : J.B.B.C., 5, 153 (1959).

28) J.P. Persijn and U. Th. Daems: Stain Techn., 39, 125 (1964).

29) E. Robbins and N.K. Gonates: J.Cell Biol., 20, 356 (1964 a).

30) Idem. : ibid., 21, 429 (1964 b).

31) E. Robbins and G. Jentzsch : J. Histochem. and Cy. tochem., 15, 181 (1967).

32) S.I. Rosen : Stain Techn., 37, 195 (1962).

33) J.S.Sutton : ibid., 40, 151 (1965).

34) H.G.Sheffield : ibid., 40, 143 (1965).

35) E.Sparvoli, H. Gay and B.P. Kaufman: ibid., 40, 83 (1965).

36）渡辺強三 : 解剖学雑誌, 41, 付 8 (1966).

37) J.H. Yardley, M.W. Heaton, L.M. Gaines and L. E.Shulman : Bull. Johns Hopkins Hosp., 106, 381 (1960).

\section{花粉の膜構造と花粉アレルギー}

\section{上 野 実 朗}

静岡大学理学部生物学教室

大気中に浮遊する花粉や胞子は，ときには吸入アレル ゲンとして，鼻炎，眼炎，気道疾患の原因となる。これ らの疾患は花粉症，花粉アレルギーといわれ，呼吸困難 を伴い，涙や鼻水が出て止まらず，また，就寝中に発作 の㧍きる場合もある。

筆者はいろいろの花粉を扱って 20 年以上になるが, 花粉症の打もな原因となるのはブタクサ（キク科，Ambrosia elatior) である. 筆者の研究の対象は長く針葉樹 であったので，マッ，スギなどの花粉は多量に吸入され てよいはずであるが，これが原因という証明は皮䖉反応 からはでてない、ブタクサは都会地周辺にはごく普通な 雑草で, 扣そらく明治の初めに北アメリカから横浜を経 て入ったものと考觉られ，東京大学には明治 13 年(1880) の標本がある. 大形の一年草で雌雄同株，9１0 月に開 花して多くの花粉を飛散する. 花粉症をおこす時期は, 原因となる花粉の飛散する時期によってきまる．空中に 花粉が飛散，浮遊していることは，花粉採集台によって 簡単に観測できる。また，どの花粉で扔かされているか を知るためには，花粉抽出液をアレルゲンとした皮膚反 応によるのが普通である。

花粉の抽出には, DP 液（デキストロース $45 \mathrm{~g}$, 重曹 $2 \mathrm{~g}, 7 ェ ノ ー ル 5 \mathrm{~g}$, 蒸留水 $1,000 \mathrm{ml})$, Coca's solution $(\mathrm{pH}$ 8.2), Evans' buffered saline (pH 7.0), Stranss and Spain's buffered sodium formaldehyde sulfoxylate ( $\mathrm{pH}$ 7.4) が用いら れている. 東大医学 部物療内科では, 肉 眼で異物を除去した 花粉を 10 倍量のエ 一テルで脱脂, 乾燥 後, 10 倍量の DP 液 を加えて振燳, 48 時 間抽出, 濾過後, 濾 液をセロファンチュ ーブで 48 時間透析,

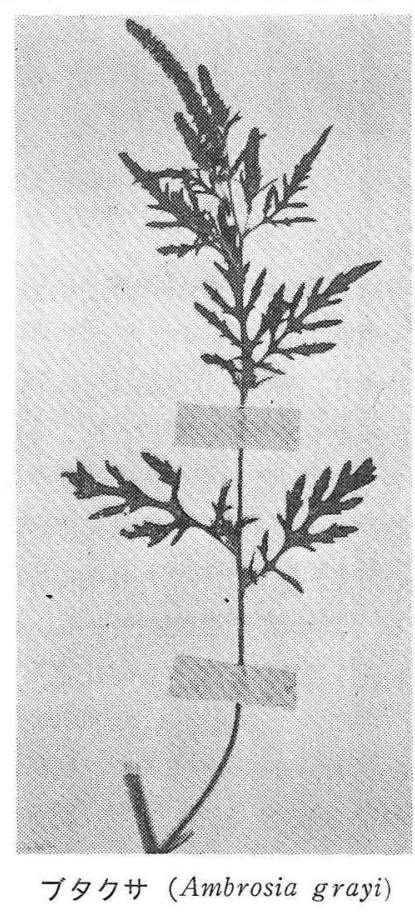

濾過後, 凍結乾燥によって, 10 倍まで濃縮して, 花粉 抽出液の原液としている。 また, 大阪大学医学部（山村 教授）では，ッベルクリン活性ペプチド（tuberclin active peptide, TAP)の抽出精製法にならって, 皮内反応 活性因子を抽出している. 非脱脂ブタクサ花粉 $1.5 \mathrm{~g}$ を 約 20 倍量の $0.1 \mathrm{~N} \mathrm{HCl} \mathrm{で} 37^{\circ} \mathrm{C}, 48$ 時間抽出し, 遠沈, 濾過後, $1 \mathrm{~N} \mathrm{NaOH}$ を加えて $\mathrm{pH} 7.0$ とし，上清に等量 の飽和ピクリン酸を加壳て黄色の沈殿を生じさせる.こ のピクリン酸沈殿画分を少量の $0.1 \mathrm{~N} \mathrm{NaOH} に て$ 溶解し, 